\title{
LR White Embedding Technique Allows Cell Selection before Sectioning; for Either Adherent Cultures or Tissues
}

\author{
P.E. Kysar and G.N. Adamson \\ Department of Medical Pathology and Laboratory Medicine, U.C. Davis, Davis, CA, 95616
}

LR White resin embedding [1] has been challenging for adherent cultured cells or a thin tissue that needs to be sectioned in a flattened state for immuno-labeling. Selection of cells within a flatly embedded sample has been compromised by the depth of the resin and requirement for restricting air. It has also been challenging to microwave-polymerize $\left\{\right.$ PELCO ${ }^{\circledR}$ BioWave, Cat. \# 36500\} submerged under water [2]. G. Ning in 2008 utilized a freeze-substitution chamber to UV or heat-polymerize chamber slides with cells [3]. Since we do not have such a unit, we devised the method outlined below. Cells grown on Aclar ${ }^{\circledR}$ \{Ted Pella cat\# 10503-25\} [4] on a $25 \mathrm{~mm}$ disk can be embedded in a hinged snap cap closure polypropylene capsule chamber $\{$ Cat. \# 21460, Ted Pella\}. Its limited depth allows easy light microscopy viewing and choice of cells for thin sectioning. A similar technique can be utilized for a thin sample that may not lie flat; accomplished by sandwiching between Aclar ${ }^{\circledR}$ sheets. The capsule holds $25 \mathrm{~mm}$ round-cut pieces of Aclar ${ }^{\circledR}$ with cultured cells. We have alleviated the problem of drying often encountered when embedding cells cultured on Aclar ${ }^{\circledR}$. A carrier was made \{Pap Jar, Evergreen Scientific 240-5400-L8K\} with holes in the bottom to move Aclar ${ }^{\circledR}$ pieces between solvents and into resin. Because the Aclar ${ }^{\circledR}$ is only physically manipulated twice, once when it is placed in the carrier and again when it is transferred to the embedding capsule, there is less likelihood of improper orientation. A standard protocol is utilized including a 30 minute incubation of $0.1 \%$ tannic acid before dehydration and a 60 minute $2 \%$ uranyl acetate in $70 \%$ ethanol during the dehydration series [2]. Cells are placed facing the interior of the capsule. A ring of $25 \mathrm{~mm}$ outside diameter Tygon ${ }^{\circledR}$ tubing with a $5 \mathrm{~mm}$ thickness is added to the capsule before LR White filling and cap closure to keep the Aclar ${ }^{\circledR}$ flat. Submersion of the capsule was achieved utilizing the PELCO ${ }^{\circ}$ microwave Capsule Holder with Lid \{Ted Pella Cat\# 36131$2\}$. Once polymerized, the single layer of Aclar ${ }^{\circledR}$ is peeled from the polymerized block of cultured cells viewed and cut out with a jewelers saw to section. The sandwich of Aclar® with thin tissue sample can have the outside layer peeled away before viewing and then gluing to a blank for sectioning [5].

References

[1] G.R. Newman, LR White Embedding Medium for Colloidal Gold Methods. In: Colloidal GoldPrinciples, Methods and Applications, Vol. 2. M.A. Hayat, ed. Academic Press, Inc., New York, (1989) 48-71.

[2] Pelco® Technical Notes 1818118182 TN 0602

[3] G. Ning, Microscopy Today, 1 (2008) 38-40.

[4] Kingsley R.E. and N.L. Cole, Journal of Electron Microscopy Technique (1988) 10:77-85.

[5] Our thanks are extended to Wei Liu and Elias Bassil for graciously supplying cultured cells and roots. 


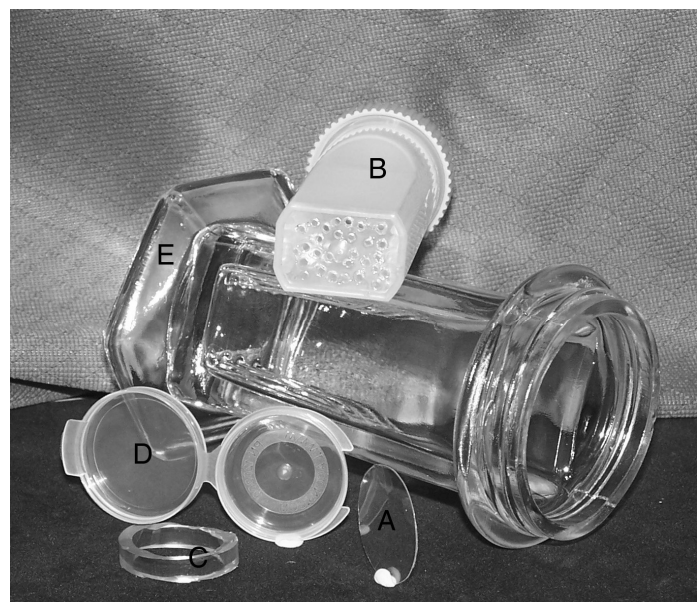

Fig. 1. A) Aclar disk B) Transfer unit C) Flattener D) Embedding Capsule E) Solvent container.

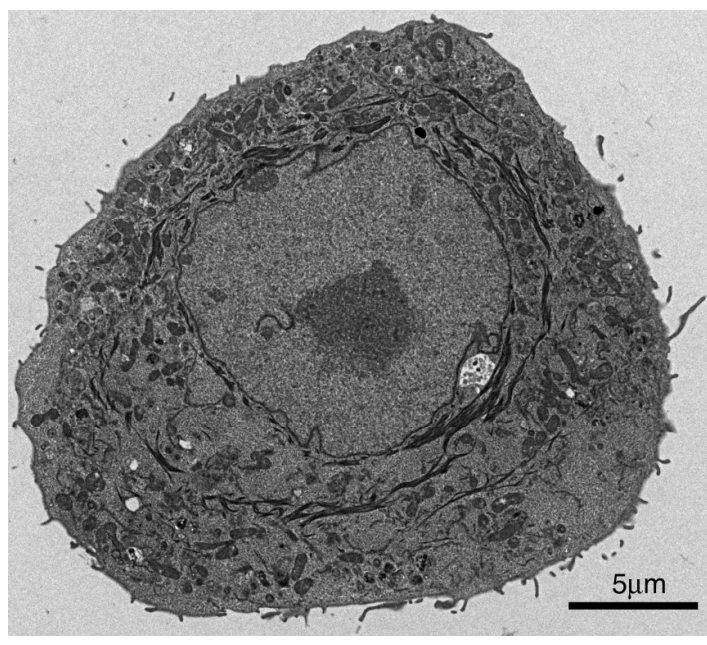

Fig. 2. TEM of cultured cell embedded in LR White. The cell was osmicated.

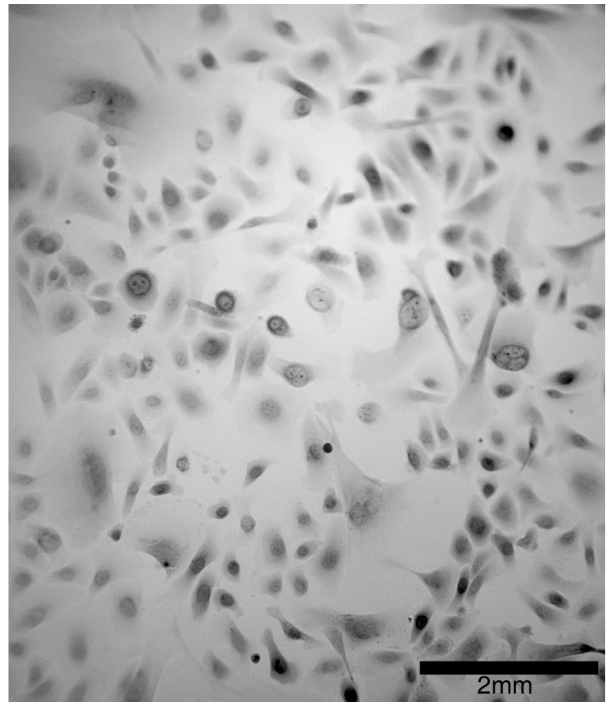

Fig. 3. Light micrograph of embedded cells. The cells were osmicated.

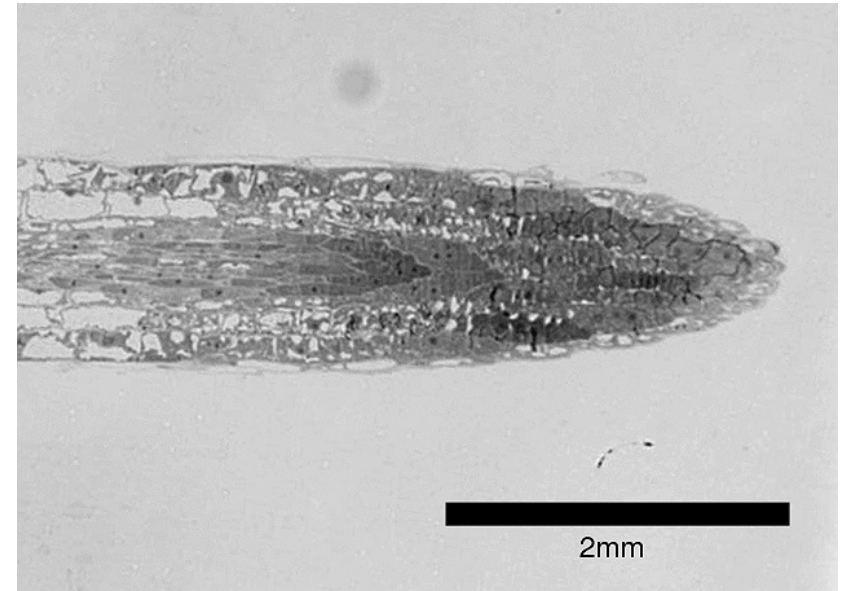

Fig. 4. Light micrograph of root tip embedded in LR White. 